Vol. 17 (2008): 193-209.

\title{
Policy-related transaction costs of agricultural policies in Finland
}

\author{
Markku Ollikainen $^{1 *}$, Jussi Lankoski ${ }^{2}$ and Sami Nuutinen ${ }^{1}$ \\ ${ }^{1}$ Department of Economics and Management, PO Box 27, FI-00014 University of Helsinki, Finland, \\ ${ }^{2} O E C D$, Directorate for Trade and Agriculture, Paris, France \\ *e-mail: markku.ollikainen@helsinki.fi
}

\begin{abstract}
This paper assesses policy-related transaction costs (PRTC) associated with the main agricultural and agri-environmental policy instruments in Finland. We find that area-based income support measures entail low transaction costs as expressed in percent of payments, not only in Finland but also in other European countries. Moreover, transaction costs in the Finnish agri-environmental programme are surprisingly low. Within the agri-environmental programme, transaction costs increase with more targeted and differentiated agri-environmental measures. For the basic mandatory measures, these costs are even lower than the transaction costs for the area-based income support measures. What regards the most differentiated policy measures such as conservation of special biotopes or establishment of riparian buffer zones, transaction costs increase considerably. Combining these findings with the actual targets of the Finnish agricultural policies provides indirect evidence about the impacts of policy instruments and the efficiency of administration in implementing the instruments. For area-based income support measures, the Finnish administration seems to work very efficiently. For water protection targets, enforcement and division of labour within the administration seem to be insufficient.
\end{abstract}

Key-words: transaction costs, agricultural policies, targeting, efficiency of administration

\section{Introduction}

Agricultural policy measures have traditionally required administration and monitoring. Recent policy shifts from commodity production coupled support payments towards decoupled payments that are targeted to specific environmental or farm income objectives will further increase administration and monitoring of policies (OECD 2007). Decoupled and targeted policies imply increased administration and monitoring, and therefore also higher implementa- 
Ollikainen, M. et al. Policy-related transaction costs of agricultural policies in Finland

tion costs for the government. Administrative costs of agricultural policies accrue at national, regional and local levels of administration. It has become commonplace to name these costs as policy-related transaction costs, PRTCs (see OECD 2007).

PRTCs belong to the more general class of transaction costs, introduced by Ronald Coase (1937) when explaining the nature of firms. The concept has been further developed especially in the work of Williamson (1985). OECD has given the following broad definition of transaction costs: "Broadly defined, transaction costs could include all costs associated with any allocative decision regardless of whether the decision is made in a market or by government" (OECD 2007, 21). Furubotn and Richter (1998) suggest that the broadly defined transaction costs can be divided into institutional transaction costs, managerial transaction costs and market transaction costs. The policy related transaction costs belong to the class of institutional transaction costs (OECD 2007). They cover the costs associated with the transaction between the government and farmers, that is, costs that are associated with a given policy or policy reform.

PRTCs are important for any policy or policy reform for two reasons. First, tracking and measuring PRTCs helps to assess the costs of public administration and to improve administrational efficiency, thereby making better use of public funds. For instance, a comparison of PRTCs between the EU countries may reveal important differences in the efficiency of national administration. Second, accounting for PRTCs is important for designing policy alternatives and choosing optimal policies. Recent policy reforms imply increased targeting, that is, improved precision of policies. However, increasing precision increases policy-related transaction costs in a percent of payments (see Vatn et al. 2002). Therefore, a good grasp of PRTCs is required to find a policy that has a good balance between improved precision and increased transaction costs.

Indeed, there has been a lot of policy debate concerning whether the potentially higher PRTCs of more decoupled and targeted policies can be large enough to offset the economic benefits of such policies (for a comprehensive treatment of
PRTCs of agricultural policies, see OECD 2007). As shown by Vatn (2002) and others, the tradeoff between the precision of agri-environmental policies and the associated PRTCs is obvious. For instance, reducing nitrogen runoff can be shown to require a combination of a fertilizer tax (restriction) and buffer strip payment that are differentiated according to the land productivity and environmental sensitiveness of field parcels. However, accounting for the transaction costs may reveal that adhering to uniform instruments instead of differentiated instruments is cheaper for the society (see Lankoski and Ollikainen 2003). Hence, when designing policies, the key question is how great the PRTCs are.

It is somewhat surprising that, despite the fact that the importance of PRTCs for policy choice is widely recognized, PRTCs have seldom been included in formal models for agricultural and agri-environmental policy making (OECD 2007). Moreover, there are only a few studies that provide empirical estimates of PRTCs of agricultural and agri-environmental policies. These include notably Falconer and Whitby 1999, Falconer et al. 2001, Falconer and Saunders 2002, Mann 2000, McCann and Easter 1999, McCann and Easter 2000, Vatn et al. 2002, and Rørstad et al. 2007. The common way to define PRTCs in this literature has been to express them as a percentage of transfers.

Overall, this empirical literature shows that there is huge variation in PRTCs between different agricultural and agri-environmental policy instruments. As a percent of transfers or payments, PRTCs range from less than $1 \%$ up to over $110 \%$ (see e.g. OECD 2007 and Rørstad et al. 2007). Studies demonstrate that payments through commodities, arable area payments and payments based on livestock numbers have the lowest PRTCs (see e.g. Vatn et al. 2002, McCann and Easter 1999, Falconer et al. 2001). Not so surprisingly, individually tailored agri-environmental management agreements have the highest PRTCs (McCann and Easter 1999 and Vatn 2002). Quite clearly, the number of transactions decreases PRTCs (Falconer et al. 2001). Moreover, some studies suggest that there is a significant learning effect, which exerts downward pressure on PRTCs in the longer run (Falcon- 
Vol. 17 (2008): 193-209.

er and Whitby 1999) as an indication of improved efficiency of administration. Finally, evidence from expenditure data from U.S. conservation programs shows that there are substantial transaction costs in developing and rolling out conservation programs in their initial years, relative to ongoing costs once programs are established (OECD 2007).

In this paper we assess the PRTCs of the main agricultural and agri-environmental policy instruments in Finland. Like Vatn et al. (2002) and Rørstad et al. (2007), we focus on the costs of implementation of these policies and omit the set-up costs (initial and closing costs of a program). The farmers' transaction costs are also omitted here as they are subject to another study. We collected the data from all levels of administration by using personal interviews that covered all ministries involved with agricultural policy implementation. We interviewed the representative regional and municipal authorities in Southern Finland and generalized these results to the rest of Finland. Given that our focus is on the implementation of agricultural and agri-environmental policies, the data contain working time, average salaries, and computer costs and other operational costs.

The main contribution of this paper is to provide, for the first time, information on the PRTCs in Finland. We contribute to the international literature in two ways. First, we contrast the Finnish PRTCs to those of Norway, which has similar agricultural conditions. Also, we make comparisons of PRTCs between selected EU countries; this brings indirect information about how the administrative efficiency, that is the effectiveness and capability of the administration to implement policy measures, differs between these countries. Second, we link transaction costs to the success of policies in achieving their targets and assess how well the division of PRTCs across administrations and their efforts in designing, implementing and monitoring helps in achieving those targets.

The rest of the paper is organized as follows. In the next section, a conceptual framework of PRTCs is presented and policy instruments included in this study are reviewed. This is followed by a description of data collection, the estimation results and a comparison of those results with estimates from other EU countries. A concluding section ends the paper.

\section{Framework and overview of policy measures}

In this section, we describe the conceptual framework for identifying relevant elements of PRTCs and present some typical hypotheses that affect the size of the costs. We then discuss the agricultural policy measures for which the data are collected.

\section{Policy-related transaction costs: a framework}

The key concept of this study is that of policy-related transaction costs of agricultural and agri-environmental policies. To discuss PRTCs of agricultural policies with a sharp focus, we distinguish between the set-up costs and running costs of PRTCs. The set-up costs of PRTCs refer to initial and closing costs (i.e., the costs related to initiating or closing a program) of any policy, including required agricultural census systems. Typically, the implementation and monitoring system, such as the EU's IACS (Integrated Administration and Control System) takes the main share of set-up costs. The running costs in turn refer to all ongoing variable and fixed costs of policy implementation in practice.

Set-up and running costs have an interesting mutual relationship. Set-up costs, typically lumpsum costs, may originally be high, but after the establishment of the system these costs are sunk, so that it is the running costs of a policy that really matter. Modifying Vatn (2001), we illustrate this relationship in Figure 1, where the vertical axis describes PRTC and the horizontal axis the precision of the policy in question. Precision is defined as the degree to which the desired target is achieved and described graphically as the distance between the desired and realized situation. 
Ollikainen, M. et al. Policy-related transaction costs of agricultural policies in Finland

Figure 1 illustrates two alternative policies: Policy 1 with associated transaction costs $\left(\mathrm{P}_{1}\right)$ entailing high set-up costs, $F$, but low running costs $t s(p)$, and Policy 2 with associated transaction costs $\left(\mathrm{P}_{2}\right)$ with zero set-up costs but high running costs $T S(p)$. As Figure 1 demonstrates, despite the fixed costs, the total PRTCs under Policy 1 are lower than those of Policy 2 when the policy precision level is higher than $p^{\prime}$. The important lesson of Figure 1 is, thus, that existing implementation and monitoring systems, such as the EU's IACS, entail sunk set-up costs but can benefit many alternative policy designs. For this reason, the focus of the study is on running costs of policy instruments, because most likely the running costs differ significantly from one policy measure to another.

The link of PRTC to actual policy and the importance of understanding transaction costs are

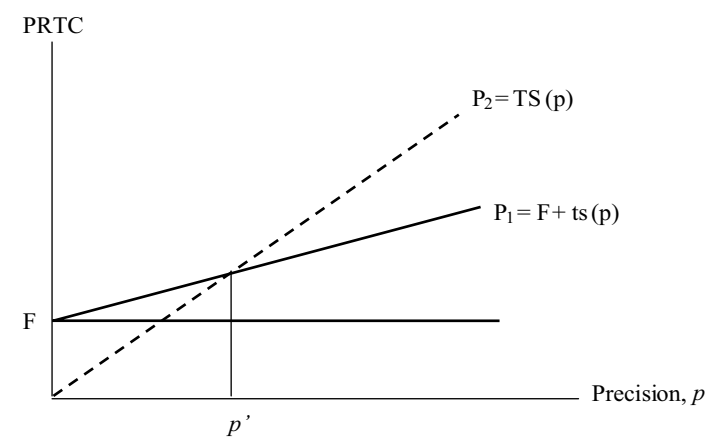

Fig. 1. Set-up costs, unit costs and the precision of policies

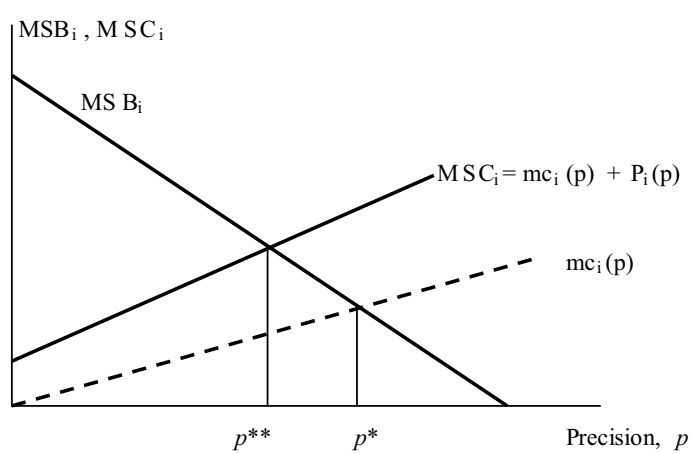

Fig. 2. The impact of PRTCs on optimal policies illustrated in Figure 2, which describes the marginal social costs (MSC) and marginal social benefits (MSB) of a given policy $i$ as a function of its precision. The MSB curve is decreasing in precision and varies in the type of the good in question. The vertical axis of Figure 2 measures marginal social benefits and marginal social costs of a policy whereas the horizontal axis measures the precision of this policy.

In Figure 2, if transaction costs are neglected, the optimal policy in terms of its precision would be $p^{*}$. However, at that point the marginal social benefits are lower than the overall marginal social costs comprising transaction costs. Hence, the optimal policy would be to choose $p^{* *}$, which implies less precision in the policy.

OECD (2007) distinguishes between three main sub-categories of PRTCs for budgetary payments for agricultural policies: initial and closing costs (set-up costs), implementation costs (running costs) and farmers' participation costs. ${ }^{1}$ Specific items under each category are represented in Figure 3.

PRTCs occur first at the governmental level, where the policy is explored and designed. The designed policies need to be enacted and the required consensus between government and civil society has to be built. Policy implementation comprises the distribution of support and monitoring and control. Distribution of payment comprises the identification of beneficiaries, processing of applications and the provision of payment. The processing of applications may sometimes need further fine-tuning and special conditions, individual or collective projects and technical assistance. Eligibility and compliance need to be monitored. Enforcement and litigation might follow, if required compliance is not achieved. Participation costs refer to all costs that farmers have to bear to participate in the policy (OECD 2007).

In this study the focus is on the middle subcategory, the costs of implementing agri-environ-

1 This is by no means the only way of defining the relevant transaction costs. For instance, Dahlman (1979) breaks up the transaction costs in three components: the cost of information gathering, the cost of contracting and the cost of control. 
Vol. 17 (2008): 193-209.

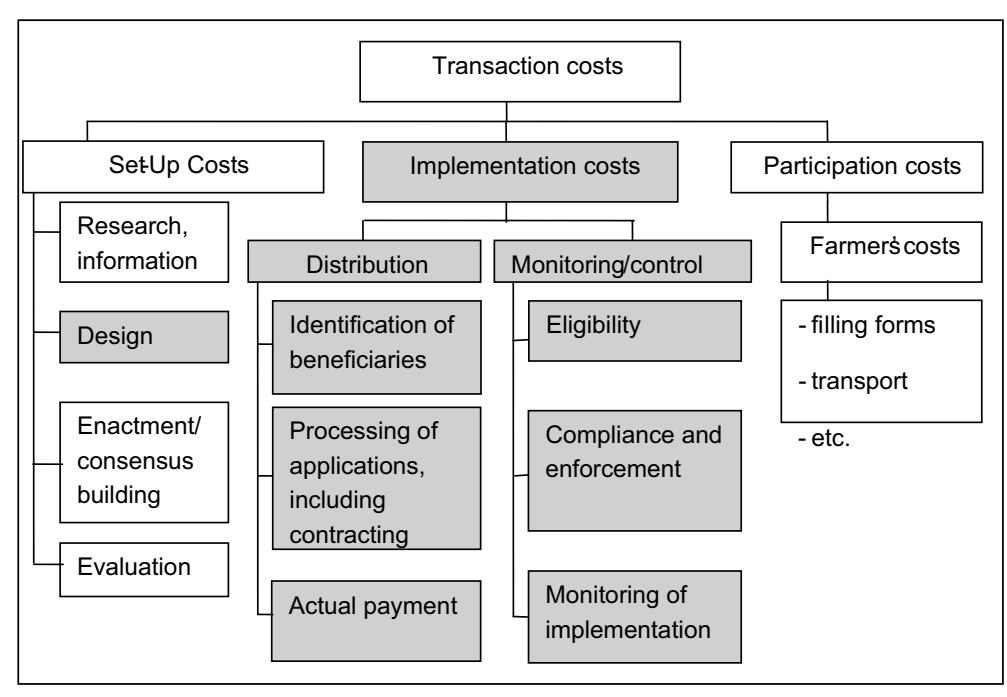

Fig. 3. Sub-categories of policy-related transaction costs for the provision of budgetary payments - modified from OECD (2007) and Mann (2000). mental policies. As we analyze administration, the participation aspect is omitted, as well as set-up costs. However, given that agri-environmental policies are revised every five to seven years, we include the costs of design (which has in practice been fine-tuning in Finland) in our analysis. The costs identified in Figure 3 for this study can be assessed using either direct interviews, top-down or bottom-up approaches (for these methods, see OECD 2007).

As for the expected size of the identified cost items, we follow Williamson (1985). He identifies three main factors affecting the transaction costs for different goods: asset specificity, frequency and uncertainty (for a discussion, see Milgrom and Roberts, 1992, 303-313). Rørstad et al. (2007) applied these concepts to agri-environmental policies as follows. If asset specificity (variation in the quality of the good in question) is high, policies targeted to it may entail high PRTC, and vice versa. Hence, environmental goods, such as local landscape features and semi-natural habitats, imply that agri-environmental policies targeted directly to their provision may have high PRTCs. By contrast, targeting market goods with low asset specificity, such as commodities, fertilizers and pesticides en- tails potentially low PRTCs. The higher the transaction frequency (how often the transaction is undertaken, or how many operations or contracts can be treated equally) and the number of agents, the lower the PRTCs per program participant or per contract will be. Uncertainty relates to behavior under asymmetric information; the higher the information gap the higher the PRTCs. Uncertainty and PRTCs are negatively linked to the frequency of transactions, as frequent transactions create trust (Rørstad et al. 2007). Note that through these features PRTCs occur at all stages of the policy process: design, implementation, monitoring and evaluation of policy.

\section{Agricultural and agri-environmental policies in Finland}

Before the implementation of the Single Farm Payment Scheme as part of the Mid-Term Review of the EU Common Agricultural Policy, the Finnish agricultural policy consisted of the following main agricultural support measures: CAP compensation payments, Compensatory allowances (support 
Ollikainen, M. et al. Policy-related transaction costs of agricultural policies in Finland

for Less Favoured Areas, LFA), National support and Agri-environmental support. We assess the PRTCs for all these support forms. In terms of our framework, we can expect that the PRTCs for area-based CAP support (CAP and LFA payments) and National support differ from those of the agrienvironmental support. While the other support measures are frequent, simple and subject to easy monitoring, agri-environmental support measures are less frequent, differentiated and more subject to opportunistic behaviour due to asymmetric information. Hence, the natural hypothesis is that the other examined support payments entail lower PRTCs than agri-environmental support payments.

CAP compensation payment is paid on the basis of the arable area and the number of animals and it constitutes a central policy instrument in the common agricultural policy of the EU. These area payments are based on regional reference yields on the basis of historical production. Area-based CAP support also includes the so-called drying aid $(24 € /$ ton $)$ in Finland and in Northern Sweden. The amount of support is $295 € /$ hectare in support area $A, € 243$ /ha in areas B and C1 and $€ 200$ /ha in areas C2-C4 (Niemi and Ahlstedt 2005). The location of different agricultural support areas in Finland is shown in Figure A1 in Appendix and the level of payments in Table A1 in Appendix. CAP support is fully financed by the EU. Compensatory allowances (LFA support) are intended to equalise differences between different agricultural regions, guarantee farming and maintain the rural population. LFA support is paid in all areas of Finland and the average EU contribution is $32 \%$. The LFA support is $€ 150$ /ha in support area A, $€ 200$ /ha in support areas $\mathrm{B}$ and $\mathrm{C} 1$ and in support areas $\mathrm{C} 2-\mathrm{C} 4$ it is $€ 210 /$ ha. (Niemi and Ahlstedt 2005).

Acreage-based national support is divided into four main policy measures: Northern aid, National aid for Southern Finland, National supplement to the agri-environmental support, and National supplement to the LFA support. These payments are intended to secure the preconditions for Finnish agriculture in different support regions and production lines. The support is based on cultivated area and crop, livestock units, and support area (Niemi and Ahlstedt 2005).
The agri-environmental support compensates the farmers for extra costs incurred and income losses due to the undertaking of environmental measures. The contribution of the EU is on the average 55 percent (Niemi and Ahlstedt 2005). The agri-environmental support consists of basic measures, additional measures and contracts for special environmental measures. There are five basic mandatory measures. A farmer that participates in the agri-environmental support scheme gives a commitment to the basic measures for five years. The amount of support is $€ 93 / \mathrm{ha}$. In addition to these five basic measures, livestock farmers have a sixth measure concerning the handling of animal manure and for that they receive an extra payment so that the support for livestock farmers is $€ 117 / \mathrm{ha}$.

Mandatory basic measures are as follows. Environmental planning and monitoring in farming: the objective of this measure is to establish an active planning and monitoring system. Basic fertilisation levels of arable crops: here the objective is to reduce the nutrient load to surface waters, ground waters and emissions to air by a more precise use of fertiliser and manure. The objective of plant protection is to reduce pesticide emissions by means of training and testing of the equipment used in the spreading of plant protection products. Headlands and filter strips prevent and reduce the runoff of nutrients and soil particles to watercourses. Maintaining biodiversity and landscape aim at preserving the traditional biotopes and open arable areas shaped by agriculture. Basic measures on livestock farm aim at reducing nutrient runoff and emissions related to the storing and handling of manure (Kröger et al. 2004).

Besides the mandatory basic measures, each farmer has to select one additional measure. For this study, the following three measures were selected. More precise fertilisation aims to reduce nutrient loads by increasing precision in the combined use of manure and chemical fertilisers. Plant cover in winter and reduced tillage aims to reduce erosion and prevent runoff of particulate phosphorus and nitrogen into surface and ground water. Additional measures on livestock farms aim to reduce nutrient loading, promote the welfare of production animals 
Vol. 17 (2008): 193-209.

and reduce ammonia emissions from manure storages. (Kröger et al. 2004)

Special environmental measures consist of environmentally more effective measures and they are targeted to a limited number of farmers. Contracts are made for five or ten years. In order to be eligible for these measures, the farmer must implement the basic and additional measures as well. The following special measures were selected for this study. Buffer zones aim to reduce erosion and nutrient runoff through the establishment of at least 15 meters wide buffer zones to those field parcels that have a steep slope towards a watercourse. Traditional biotopes aim to preserve and enhance the biodiversity of flora and fauna in traditional biotopes (such as meadows and pastures). Their purpose is also to maintain rural cultural heritage and landscape values. (Kröger et al. 2004)

\section{Levels of administrations and generation of data}

The data for this study was gathered in 2005. Following the logic of Figure 3, we identified the levels of public authorities participating in the public implementation of the Finnish agricultural policies. The levels of administration follow the Integrated Administration and Control System (IACS) of the EU and comprise the national, regional and municipal authorities. Three ministries are participating in the administration of the programmes at the national level. These ministries are: the Ministry of Agriculture and Forestry, the Ministry in Industry and the Trade and Ministry of the Environment. The Ministry of Agriculture and Forestry is responsible for the design of policies.

Administration at the regional level is conducted by the Rural Departments of the Ministry in Industry and Trade and the Regional Environment Centres of the Ministry of the Environment. Finally, at the local level there are municipal agricultural authorities. All levels of administration participate in the implementation of agricultural policies.
Municipal agricultural authorities, governed by the Rural Departments, handle, for instance, farmers' support payment applications and other related issues. Regional Environment Centres and Rural Departments also directly contact farmers when promoting alternative policy measures, designing prescriptions and monitoring the implementation of the measures. The monitoring and enforcement of policy is accomplished by the IACS. Monitoring of policy consists of measurement with satellites image and farm and field inspections. It is carried out by the Ministry of Agriculture and Forestry, Rural Departments, Regional Environment Centres and municipal authorities.

Our interviews covered two ministries, the Ministry of Agriculture and Forestry and the Ministry of the Environment. We chose the representative Rural Department and Regional Environment Centres from Southern Finland, because it is the most important area for crop production. The interviews began from the Ministry of Agriculture and Forestry. Here, the data gathering method was, exceptionally, a top-down approach. Information of total person-years was collected from electronic telephone directory that includes task descriptions. Based on that, person-years were divided between policy measures. The overhead costs were derived from the ministry's report of administration productivity program.

Data from the Ministry of the Environment are based on direct interview in the department of Environmental Protection. The duties of the Ministry of the Environment (in year 2004) relate to agrienvironmental support design, implementation and follow-up. In the interview, the share of basic measures was about $10 \%$, and the additional and special measures took up $20 \%$ and $70 \%$ of labour input, respectively. The share is the same for all duties. On the basis of this information and allocated time the person-years within the measures and duties were divided.

The Rural Departments of Employment and Economic Development Centres are supervised by the Ministry of Agriculture and Forestry and the Ministry in Industry and Trade. There are a total of 15 Rural Departments. The Varsinais-Suomi Rural Department was chosen as the representative office 
Ollikainen, M. et al. Policy-related transaction costs of agricultural policies in Finland

because of its location in the main crop production area. Within the Rural Department, the Support and Environmental Service unit was the main focus of this study.

In the interview, annual task calendar was used to get overall picture of activities related to our study. Monitoring is the most important duty of the Rural Departments. That includes the monitoring farmers in co-operation with municipal authorities and the Regional Environment Centres, monitoring municipal authorities, and different cross-examinations. Monitoring information is registered at very high accuracy. This proved helpful in the division of the labour input for different policy measures and administrative duties. Consequently, these data can be considered to be very reliable.

There are a total of 13 Environment Centres. The Centre of Southwest Finland was selected as a representative office. Agricultural duties in the Regional Environment Centre are supervised by the Rural Group of Environmental Techniques and Management Department. The duties of the Regional Environment Centre concern only special agri-environmental measures. Labour years were allocated to the policy measures by similar time usage estimates as in the case of the Ministry of Environment. This entails some uncertainty when it comes to allocation of person-years, yet it is based on the assessment of a specialist.

In 2004, there were altogether 444 municipalities in Finland, out of which we chose Loimaa and Somero as the representative municipalities. Data are based on interviews of persons responsible for municipal rural services. The division between the duties and measures is based on evaluated shares of person-years. Labour and overhead costs were derived from settlement of accounts.

We generalized the data from the interviews to the whole Finland as follows. We assumed that the unit implementation costs do not differ between areas; they differ only across the measures. Under this assumption we can define a coefficient for each measure as the share of support payments paid in each region to the overall support payments in the whole country for this measure. Thus, the regional total transaction costs of the Rural Departments, Environment Centres and Municipal are calculated as a sum of constant unit transaction costs from the acreage-based support payments and from the agrienvironmental support payments multiplied by the share of payments by the regional authorities in the payment of the whole country.

\section{Policy-related transaction costs for the Finnish agricultural policy}

We follow the convention and express the transaction costs as a percentage of the payment transfers. This is generally regarded as the most convenient way to compare different policy measures. Using percentage expressions leans to an assumption that transfers are a proxy for the size of the policy or the value of social outcomes. The results are generalized to the national level and reported in Table 1.

In Table 1, we aggregated the area-based CAP, LFA and national support into one figure, as the PRTCs associated with each support measure were quite similar. This only reflects the fact that the measures by themselves are quite similar. The PRTCs of the basic, additional and special measures are from the interviews. While it was impossible to impute costs separately for the specific submeasures among the basic measures, we were able to define the costs for some selected additional and special measures that represent a set of fairly differentiated and targeted measures. This was done by assuming that the costs of the agri-environmental policy measures vary with the number of hectares they are applied to.

From Table 1, the basic lesson is quite evident. PRTCs for CAP, LFA and national supports are relatively low. These measures are very frequent and simple, and given the IACS system, they are easy to monitor. Thus, PRTCs should be low. As we will shortly see, these figures are perfectly in line with findings in Norway and many other countries.

Interestingly, the PRTCs in percent of the total agri-environmental support are quite low, too. They 
Vol. 17 (2008): 193-209.

are only slightly higher than the PRTCs associated with the area-based support. The explanation for this feature is two-fold. First, the share of basic measures in the agri-environmental support payments is large, and the farmers' participation rate in basic measures is high (more than $92 \%$ of farmers), making thereby the magnitude of payments large, since $90 \%$ of agri-environmental funding is allocated to basic and additional measures and only $10 \%$ to special measures. The high participation rate and large payments decrease the percent PRTCS. Second, the enforcement costs of basic measures are fairly low: All basic measures addressing land use and crop choices are quite easy and inexpensive to monitor due to establishment of the IACS system. However, a sub-measure that is difficult to monitor and enforce is the application limits for fertilizer use.

We next focus in detail on the basic, selected and additional measures within the agri-environmental support programme. The basic measures have low PRTCs - even lower than those associated with the CAP, LFA, and national support payments. In line with our hypothesis, PRTCs increase when moving from basic measures to selected additional and special measures. The selected special measures entail the highest PRTCs 33.1\%.
Within the selected additional measures, the measure on livestock farms has fairly low PRTC; it is only about half of the average PRTCs for additional measures. Interestingly, payments to a more precise fertilisation have higher PRTCs than other additional measures. The special measures entail high transaction costs. These arise from a large labour input for design and monitoring. The difference between percent PRTCs of traditional biotopes and riparian zones was larger than expected, since traditional biotopes are a very site-specific measure. As design and monitoring of riparian zones require significant labour input and total payments are quite low, the percent PRTCs were highest of the analysed policy measures.

Table 2 indicates how the PRTCs are associated with the area support payments and agri-environmental support at each level of administration. Also, it shows how the transaction costs emerge from the three basic operations, policy design, implementation, and monitoring.

From Table 2, the share of the Ministry of Agriculture and Forestry is almost 25 million euros, which makes $61 \%$ of the total PRTCs. The Rural Departments have PRTCs of 7.6 million euros $(18.6 \%)$; the share of municipal authorities is $13 \%$ and Regional Environment Centres 10\%. While implementation entails the highest PRTC item in

Table 1. PRTC of the Finnish agricultural and agri-environmental policy measures in the year 2004.

\begin{tabular}{|c|c|c|c|}
\hline Measure & $\begin{array}{l}\text { PRTC, } \\
€ 1000\end{array}$ & $\begin{array}{l}\text { Subsidy, } \\
€ 1000\end{array}$ & $\begin{array}{c}\text { PRTC/subsidy, } \\
\%\end{array}$ \\
\hline CAP-, LFA- and national support & 32077 & 1519000 & 2.11 \\
\hline Agri-environmental support & 8664 & 312000 & 2.78 \\
\hline Total & 40741 & 1831000 & 2.23 \\
\hline \multicolumn{4}{|l|}{ Forms of the agri-environmental support } \\
\hline Basic measures (total) & 3079 & 211000 & 1.46 \\
\hline Additional measures (total) & 2719 & 40620 & 6.69 \\
\hline More accurate fertilization & 471 & 4800 & 9.81 \\
\hline Plant cover in winter and reduced tillage & 1710 & 21270 & 8.04 \\
\hline Additional measures on livestock farms & 538 & 14550 & 3.70 \\
\hline Special measures (total) & 2866 & 8670 & 33.06 \\
\hline Buffer zones & 1131 & 2640 & 42.83 \\
\hline Traditional biotopes & 1735 & 6030 & 28.77 \\
\hline
\end{tabular}


Ollikainen, M. et al. Policy-related transaction costs of agricultural policies in Finland

Table 2. PRTCs in total (€ 1000), design (\%), implementation (\%) and monitoring (\%) by administrations.

\begin{tabular}{lcccc}
\hline Measure and authority & $\begin{array}{c}\text { Total PRTCs, } \\
€ 1000\end{array}$ & $\begin{array}{c}\text { PRTCs in } \\
\text { design, } \%\end{array}$ & $\begin{array}{c}\text { PRTCs in } \\
\text { implementation, } \%\end{array}$ & $\begin{array}{c}\text { PRTCs in } \\
\text { monitoring, } \%\end{array}$ \\
\hline CAP, LFA and national support & 32077 & 24 & 55 & 21 \\
$\quad$ Ministry of Agriculture and Forestry & 23340 & 29 & 58 & 13 \\
Ministry of the Environment & 0 & 0 & 0 & 0 \\
Rural Departments & 3678 & 0 & 0 & 100 \\
Environment Centers & 0 & 0 & 78 & 0 \\
Municipal Authorities & 5059 & 21 & 35 & 1 \\
Agri-environmental support & 8664 & 23 & 39 & 42 \\
Ministry of Agriculture and Forestry & 1641 & 39 & 14 & 22 \\
Ministry of the Environment & 7 & 29 & 19 & 57 \\
Rural Departments & 3899 & 0 & 42 & 81 \\
Environment Centers & 1973 & 51 & 76 & 7 \\
Municipal Authorities & 1144 & 23 & - & 1 \\
Total PRTCs & 40741 & - & -
\end{tabular}

the CAP, LFA and national support, PRTCs in monitoring are the biggest item in agri-environmental policy. The share of monitoring costs of the total PRTCs in agri-environmental scheme is about $42 \%$ which is almost twice as high as monitoring costs in the area payment support. However, the absolute cost is about $€ 3.64$ million, which cannot be regarded high.

Table 3 provides a more detailed look at the PRTCs associated with the mandatory, additional, and selected measures of the agri-environmental support.

Table 3 contains many interesting features. Most of PRTCs for the Rural Departments emerge from the monitoring of the basic and additional measures. In contrast, the respective figure of the local administration, the municipal agricultural authorities is just $1 \%$, although they should have in principle the best possibilities to monitor the farmers. The task of monitoring is mostly a duty of Rural Departments. Environmental centers have the role only in the case of special measures. An interesting observation is that the share of PRTCs in design is very high, $52 \%$ of total PRTC of the Environmental Centers. This is due to the fact that buffer zones and traditional biotopes require a lot of labor input to make both regional and farm specific plans for these measures. As pointed out by the referee, the design by the Environmental Centers can equally well be interpreted as the implementation of the agri-environmental policy. This would imply that the more than $90 \%$ of their PRTCs are due to implementation.

In Figure 4 we omit the allocation of PRTCs between the administrations and demonstrate how the total policy-related transaction costs are divided in aggregate between policy design, policy implementation, and monitoring.

From Figure 4, in comparison to area-based income support measures, the basic and additional agri-environmental measures imply a higher share of monitoring costs. In fact, monitoring costs represent approximately $60 \%$ of transaction costs in the case of basic and additional agri-environmental measures. In the case of specialised agri-environmental measures, the share of policy design is relatively highest, which is explained by the heterogeneous and site-specific nature of these two policy measures. Indeed, both of these special measures require a detailed site-specific planning, which in- 
Vol. 17 (2008): 193-209.

Table 3. PRTCs in agri-environmental support.

\begin{tabular}{|c|c|c|c|c|}
\hline Agri-Environmental support & $\begin{array}{l}\text { Total PRTCs, } \\
\quad € 1000\end{array}$ & $\begin{array}{l}\text { PRTCs in } \\
\text { design, } \%\end{array}$ & $\begin{array}{c}\text { PRTCs in } \\
\text { implementation, } \%\end{array}$ & $\begin{array}{c}\text { PRTCs in } \\
\text { monitoring, } \%\end{array}$ \\
\hline Basic measures & 3079 & 16 & 25 & 59 \\
\hline Ministry of Agriculture and Forestry & 851 & 39 & 39 & 22 \\
\hline Ministry of the Environment & 2 & 29 & 14 & 57 \\
\hline Rural Departments & 1624 & 1 & 0 & 99 \\
\hline Environment Centers & 0 & 0 & 0 & 0 \\
\hline Municipal agricultural authorities & 602 & 24 & 75 & 1 \\
\hline Additional measures & 2719 & 16 & 26 & 58 \\
\hline Ministry of Agriculture and Forestry & 778 & 39 & 39 & 22 \\
\hline Ministry of the Environment & 4 & 29 & 14 & 57 \\
\hline Rural Departments & 1403 & 1 & 0 & 99 \\
\hline Environment Centers & 0 & 0 & 0 & 0 \\
\hline Municipal agricultural authorities & 534 & 22 & 77 & 1 \\
\hline Special measures & 2866 & 36 & 55 & 10 \\
\hline Ministry of Agriculture and Forestry & 12 & 39 & 39 & 22 \\
\hline Ministry of the Environment & 1 & 50 & 14 & 57 \\
\hline Rural Departments & 872 & 0 & 84 & 16 \\
\hline Environment Centers & 1973 & 52 & 42 & 7 \\
\hline Municipal agricultural authorities & 8 & 22 & 77 & 1 \\
\hline Total & 8664 & 23 & 35 & 42 \\
\hline
\end{tabular}

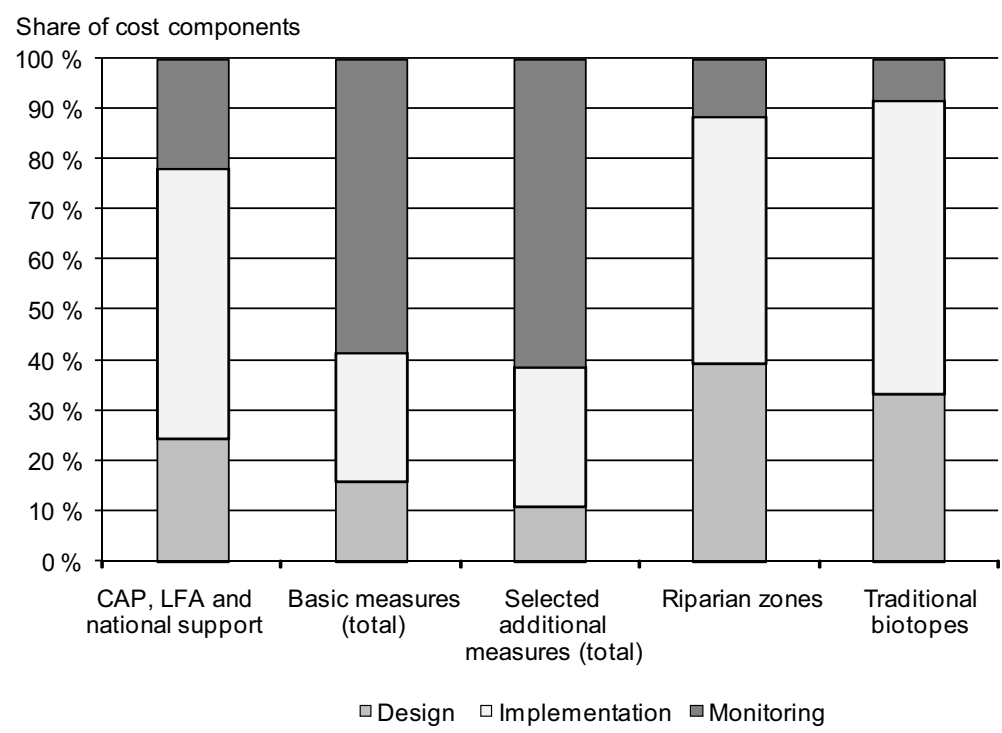

Fig. 4. Share of transaction cost components in selected policy measures. creases the labour input of environmental authorities, especially in Regional Environment Centres.

We would finally like to emphasize that when comparing the different policy measures with each other, the percent PRTCs as an indicator does not give the whole picture of the nature of policies and specific measures. The shares are strongly influenced by the level of payments and they may not entail all costs and benefits of a policy (see e.g. Vatn et al. 2002 and OECD 2007). 
Ollikainen, M. et al. Policy-related transaction costs of agricultural policies in Finland

But even more importantly, the mere size of PRTCs does not indicate much about the performance of policies. The fact that transaction costs are either high or low does not guarantee that the chosen policy measures and the administrative effort achieve the objectives and targets set for the policy. Hence, one should distinguish between the administrative efficiency of implementing a given set of policy measures and the performance of the chosen instruments in producing the desired outcomes. The level and allocation of PRTCs provide indirect evidence about the administrative efficiency in implementing the given policy measures. An efficient administration implements policies with least transaction costs. This does not, however, imply that the selected measures always have the desired impact; this depends on how well the measures are chosen and designed.

These aspects are especially important for the discussion on the Finnish agri-environmental support policy, which was originally launched in 1995 and has remained roughly the same over the years. Its goal is predominantly to reduce nutrient runoff from the fields. Additionally, it aims at maintaining agricultural landscape and safeguarding biodiversity. Empirical studies show, however, that achievements in reducing nutrient runoff have been very modest. In fact, there has not been reduction in the nutrient runoff from agriculture (Turtola and Lemola 2004). Our analysis shows one factor that may have affected the slow progress in nutrient control. PRTCs in monitoring the basic measures were relatively low indicating that monitoring effort is not expanded to a level needed for full compliance with the basic measures. This conclusion is confirmed by Turtola and Lemola (2004), who notify failures in the enforcement of agri-environmental measures. This indicates inefficient allocation of administrative efforts, but is by no means the only reason for the failure of agri-environmental support program to reduce runoff. We will return to this issue at length in the concluding section. We next turn to comparing our findings with the results obtained in other studies.

Table 4. PRTCs in the Finnish acreage-based national and traditional biotopes support, and in the Norwegian acreage and special landscape ventures support

\begin{tabular}{lrrrrr}
\hline & \multicolumn{2}{c}{$\begin{array}{c}\text { Acreage } \\
\text { support }\end{array}$} & & \multicolumn{2}{c}{$\begin{array}{c}\text { Traditional biotopes } \\
\text { and landscape ventures }\end{array}$} \\
\cline { 2 - 3 } \cline { 5 - 6 } Government agencies & $\begin{array}{c}\text { PRTCs, } \\
€ 1000\end{array}$ & $\begin{array}{c}\text { PRTCs, } \\
\%\end{array}$ & & $\begin{array}{c}\text { PRTCs, } \\
€ 1000\end{array}$ & $\begin{array}{c}\text { PRTCs, } \\
\%\end{array}$ \\
\hline FINLAND & & & & \\
Ministry of Agriculture and Forestry & 204 & 0.37 & & 10 & 0.16 \\
Ministry of the Environment & 0 & 0.00 & & 0.02 \\
Rural Departments & 1094 & 0.18 & & 393 & 6.52 \\
Environment Centers & 0 & 0.00 & 1325 & 21.97 \\
Municipal agricultural authorities & 2357 & 0.40 & 7 & 0.11 \\
Total & 5655 & 0.95 & 1735 & 28.77 \\
NORWAY & & & & \\
Ministry of Agriculture & 0 & 0.00 & & 0.02 \\
Norwegian Agricultural authority & 675 & 0.17 & & 455 & 3.31 \\
County authority & 357 & 0.09 & & 421 & 3.06 \\
Local agricultural authority & 2143 & 0.54 & 6313 & 45.90 \\
Total & 3175 & 0.80 & 7192 & 52.29 \\
\hline
\end{tabular}


Vol. 17 (2008): 193-209.

\section{Comparison of policy-related transaction costs in some countries}

We first compare our findings with those obtained for Norway by Vatn et al (2002). Vatn et al. (2002) estimated PRTCs of various Norwegian agricultural and agri-environmental policy measures. Their data is based on interviews of farmers, policymakers, and wholesalers and they determined labor cost, computer, information material, postage and general overhead costs. They focus on the running costs of policy measures because the lack of data related to set-up costs. Given that agriculture is practised in northern conditions and both countries have large rural areas with low population density, the comparison is meaningful. We restrict the comparison to the measures that are similar in Finland and Norway. Also, the total PRTCs are compared. The Norwegian currency, NOK was converted to euros using exchange rate of year 2000.
Starting from the total figures, we find that in Finland the total subsidy payment amount to $€ 1$ 831000000 and the total PRTCs is $€ 40741035$, which gives the share of PRTCs $2.23 \%$. According to Vatn et al. (2002), the respective figures in Norway were $€ 772626$ 646, $€ 905$ 239, and 2.19 $\%$ PRTC share. Hence, the PRTCs are very low and close to each others despite the differences in policy measures. This indicates that the administration is efficient in implementing the policies in both countries.

We next compare the PRTCs associated with two measures, the acreage-based national payments and landscape conservation in both countries. The acreage-based national support payments in Finland are 594 million euros and in Norway they are slightly below 397 million euros. While these support payments promote conservation of traditional biotopes, they slightly differ from each others. The Norwegian special landscape venture consists of five different measures that, in addition to traditional biotopes, include promotion of biodiversity and preservation of cultural sites. The overall payments for this purpose are 6.03 mil-

Table 5. PRTCs of acreage-based national supports and arable area payments for selected countries.

\begin{tabular}{lccc}
\hline & Subsidy & PRTC & $\begin{array}{c}\text { PRTC/Subsidy, } \\
\%\end{array}$ \\
\hline England (1998) & 1582300 & 17900 & 1.1 \\
Finland (2005) & 594000 & 5430 & 0.9 \\
Netherlands (1997) & 128000 & 8745 & 6.8 \\
Norway (2000) & 396836 & 3175 & 0.8 \\
Sweden (1996) & 418310 & 11939 & 2.9 \\
\hline
\end{tabular}

Table 6. Transaction costs in biodiversity and landscape conservation programs in selected countries.

\begin{tabular}{lccc}
\hline & $\begin{array}{c}\text { Payment, } \\
€ 1000\end{array}$ & $\begin{array}{c}\text { PRTCs, } \\
€ 1000\end{array}$ & PRTCs/Payment, \% \\
\hline Belgium & 1604 & 1065 & 66 \\
Finland & 6030 & 1737 & 29 \\
Norway & 13755 & 7192 & 52 \\
Sweden & 17073 & 4828 & 28 \\
Uk & 40430 & 9959 & 25 \\
\hline
\end{tabular}


Ollikainen, M. et al. Policy-related transaction costs of agricultural policies in Finland

lion euros in Finland and 13.75 million euros in Norway. Table 4 facilitates the comparison of the PRTCs; the Norwegian data produce using Vatn et al. 2002, Appendix 3.

As for the acreage support, the percentage cost shares are of the same size, though slightly higher in Finland. The Finnish acreage-based national support consists of four different measures, which may explain the higher estimate. The Finnish national support payment system benefits from the monitoring of the CAP support system (including CAP income support and LFA), which may underestimate the PRTCs of national acreage support in Finland. The total transfers in Finland are about 200 million euros larger than in Norway. There are also differences in the shares of different governmental agencies. The Finnish Ministry of Agriculture and Forestry bears about $37 \%$ and local authorities $40 \%$ of the costs, while the Norwegian Ministry does not have any PRTCs and local authorities bear 54\% of costs. Thus, the Norwegian support system seems to be more decentralized than the Finnish system, which follows the requirements of the EU's Common Agricultural Policy. In sum, however, the transaction costs of the Finnish and Norwegian acreage payments are very similar.

From Table 4, the PRTCs of the traditional Finnish biotopes are clearly much smaller but the explanation for this may be due to above-mentioned differences in policy measures. Still, traditional biotopes may be an efficiently administered policy measure, especially when the required level of precision is taken into account. An interesting difference between Finland and Norway is in the fact that in Norway PRTC burden lies in local agricultural authorities, whereas in Finland it is in the regional Environmental Centres; in both countries duties are decentralized but more so in Norway.

We, finally, extend our comparison to England, the Netherlands, Norway and Sweden. Again, our comparison is restricted to measures that can be expected to be quite close to each other. However, the amount of uncertainty is now much higher than in the previous comparison between Finland and Norway. We first focus on the crop area payments and then discuss conservation of traditional biotopes and other semi-natural habitats.
Table 5 condenses PRTCs of acreage-based supports and arable area payments for some selected countries (data is taken from SAI 2000). Unfortunately, the data for each country comes from different years, which makes the comparison less reliable. The general picture seems to be quite clear, though. Finland, England and Norway have low PRTCs for their area-based support measures. Sweden and Netherlands have much higher estimates for PRTCs.

Conservation measures for special semi-natural habitats and landscape ventures differ but aim at a similar type of goals. The Finnish and Norwegian systems have been presented above. Sweden has a conservation system similar to the Finnish case: cultural heritage and traditional biotopes are conserved. We do not have data from the Netherlands but from Belgium, which has roughly similar agricultural conditions as in the Netherlands. In Belgium the conservation aims at promoting pollardwillows and small landscape elements. Finally, in the UK, the aim is to conserve environmentally sensitive areas. Table 6 facilitates the comparison (the data is from Falconer and Whitby 1999b, appendix 1 summary tables and Vatn et al. 2002, appendix 3).

Irrespective of differences in measures, all countries exhibit the common feature that semi-natural habitat conservation entails much higher PRTCs than area payments. The observed range is from $25 \%$ (UK) up to $66 \%$ (Belgium). Finland, Sweden and UK have roughly similar PRTCs, between $20 \%-30 \%$, while Norway and Belgium have much higher figures. Belgium and Norway have higher figures, because their conservation measures are more comprehensive and differentiated than those in Finland, Sweden and UK. This demonstrates that increased targeting of agri-environmental measures leads to higher transaction costs.

\section{Conclusions}

Policy-related transaction costs are important for two reasons. Tracking and measuring PRTCs helps 
Vol. 17 (2008): 193-209.

us to assess the costs of public administration and to improve its efficiency. This leads to a better use of public funds. Equally importantly, accounting for PRTCs helps in the design and implementation of agricultural policy instruments and choosing the optimal policies. Optimal policies increase targeting (precision) up to the point where the marginal benefits from targeting equal the marginal policyrelated transaction costs.

We assessed the PRTCs of agricultural and agri-environmental policies in Finland for the main policy instruments. Our focus was on the costs of implementation of policies. To get some indirect information on the efficiency of the Finnish administration, we also compared Finnish PRTCs with Norway and some selected EU countries. Our method was to interview all levels of administration to produce estimates on working time, average salaries, and operational costs. The interviews covered all ministries involved with agricultural policy implementation. At the regional and municipality level we chose Southern-Finland as the study area.

The findings of this paper can be condensed as follows. First, all area-based income support measures entail low PRTCs. This holds not only for Finland but also for all Nordic countries, the Netherlands and the UK. Thus, we can conclude that the administration in Finland seems to work efficiently in implementing these income support measures. This conclusion is also conformed by the facts that there are no reported problems in transferring payments to farmers. Moreover, reported cases where farmers falsely claim for certain crop area-based supports are extremely rare, which indicates that the monitoring effort and PRTCs associated with it are at an efficient level.

Second and quite surprisingly, PRTCs in the Finnish agri-environmental programme turned out to be low, too. Within the agri-environmental programme, the share of PRTCs increases with targeted and differentiated agri-environmental measures. For the basic measures that are common to all farmers who participate in the Finnish Agri-Environmental Programme PRTCs are even slightly lower than PRTCs for the area-based income support measures. As regards the most differentiated policy measures, such as conservation of special biotopes or establishment of riparian buffer zones, PRTCs increase considerably. The same pattern can be observed for other countries, too.

Thus, the administrative efficiency in implementing the agri-environmental protection measures seems to be good. However, this is not necessarily true. Recall, the main goal of the agrienvironmental program is to reduce nutrient runoff. Thus, the low PRTCs must be contrasted with the fact that nutrient runoff reduction targets have not been achieved. Our figures showed that the administrative efforts in monitoring and enforcement were fairly low. Moreover, PRTCs revealed that in the division of labour inside administration, the local authorities do not have a key role in monitoring farms despite the fact that their possibilities for this function are the best. While the latter feature may be an integral part of the agri-environmental programme that the administration cannot change, the former aspect shows weakness in allocating the administrative efforts.

The low monitoring rate can also be linked to the high participation rate of farmers to the voluntary agri-environmental program. The high participation rate can be regarded as an indication of a generous compensation for environmental protection (compensating just for the average compliance costs would reduce the number of participants, as evidence from other EU countries shows). Generous compensations associated with low enforcement may indicate that the Finnish agri-environmental support has a flavour of an income support that is given in a "green package". In any case, our analysis demonstrates that the further development of the Finnish agri-environmental programme requires improving enforcement and the division of labour inside administration. Moreover, the examination of the transaction costs accruing to farmers and the ability of current agri-environmental measures to promote the desired environmental goals is needed to complement the analysis presented in this paper.

Acknowledgements. This paper was part of the project "Multifunctional Agriculture and Policies" funded by the Ministry of Agriculture and Forestry. This funding 


\section{AGRICULTURAL AND FOOD SCIENCE}

\section{Ollikainen, M. et al. Policy-related transaction costs of agricultural policies in Finland}

is gratefully acknowledged. We are grateful to Jarmo Salonen for helping to frame the research idea. We thank Catherine Moreddu for insightful advice and comments. The comments by two anonymous referees are gratefully acknowledged.

Disclaimer. The views are those of the authors and do not reflect the official view of the OECD or its member governments.

\section{References}

Coase, R. 1937. The nature of the firm. Economica 4:386-405.

DahIman, C.J. 1979. Problem of externality. Journal of Law and Economics 22:141-162.

Falconer, K. and Whitby, M. 1999. The invisible costs of scheme implementation and administration, in G. Van Huylenbroeck and M. Whitby, Countryside Stewardship: Farmers and Markets, Chapter 4, Elsevier Science Ltd.

Falconer, K. Dupraz, P. \& Whitby M. 2001. An investigation of policy administrative costs using panel data for the English Environmentally Sensitive Areas. Journal of Agricultural Economics, 52:83-103.

Falconer, K. and Saunders, C. 2002. Transaction costs for SSSIs and policy design. Land use policy 19:157-166.

Furubotn, E.G. \& Richter, R. 1998. Institutions and Economic Theory. The University of Michigan Press, USA.

Kröger, L. Lankoski, J. \& Huhtala, A. 2004. Agri-environmental policy in Finland 1995 - 2006. Unpublished ITAES Workpackage report.

Lankoski, J. \& Ollikainen, M. 2003. Agri-environmental externalities: a framework for designing targeted policies. European Review of Agricultural Economics 30:51-75.

Mann, S. 2000. Transaktionskosten der landwirtschaftli- chen Investitionsförderung - ein komparativer Ansatz. Agrarwirtschaft 49:259-269.

McCann, L. \& Easter K. W. 1999. Transaction costs of policies to reduce agricultural phosphorous pollution in the Minnesota River. Land Economics 75:402-414.

McCann, L. \& Easter K. W. 2000. Public sector transaction costs in NRCS programmes. Journal of Agricultural and Applied Economics 32:555-563.

Milgrom P. and J. Roberts1992. Economics, Organization and Management. Prentice Hall, Englewood Cliff, USA.

Niemi, J. \& Ahlstedt, J. (2005). Finnish Agriculture and Rural Industries 2005 - Ten Years in the European Union. Agri-Food Finland. Publications 105.

OECD 2007. The implementation costs of agricultural policies. OECD, Paris. $195 \mathrm{p}$.

Rørstad, P. K., Vatn, A. \& Kvakkestad, V. 2007. Why do transaction costs of agricultural policies vary? Agricultural Economics 36:1-11.

SAI 2000. Administration of arable payments in the Netherlands, Sweden, and England. A report by the Netherlands Court of Audit, the Swedish National Audit Office and the United Kingdom National Audit Office, April 2000.

Turtola, E. \& Lemola, R. 2004. Maatalouden ympäristötuen seuranta MYTVAS 2. Osahankkeiden 2-7 väliraportit 2000-2003. Maa- ja elintarviketalous 59. Jokioinen.

Vatn, A. 2001. Transaction costs and multifunctionality. Paper presented at the OECD workshop on "Multifunctionality: Applying the OECD Analytical Framework - Guiding Policy Design", Paris, 2-3 July.

Vatn, A. 2002. Multifunctional agriculture: some consequences for international trade regimes. European $R e-$ view of Agricultural Economics 29:309-327.

Vatn, A. Kvakkestad, V. and Rørstad P. K. 2002. Policies for multifunctional agriculture: The trade-off between transaction costs and precision. Agricultural University of Norway. Department of Economics and Social Sciences. Report No. 23.

Williamson, O.E. 1985. The economic institutions of capitalism: Firms, Markets, Relational Contracting. Free Press, New York. 
Vol. 17 (2008): 193-209.

\section{Appendix}

Table A1. Agricultural support payments in different support areas in Finland (Niemi and Ahlstedt 2005, the Finnish Ministry of Agriculture and Forestry).

\begin{tabular}{|c|c|c|c|c|}
\hline Policy measures & $\begin{array}{c}\text { Support area } \\
\text { A }\end{array}$ & $\begin{array}{c}\text { Support area } \\
\text { B }\end{array}$ & $\begin{array}{l}\text { Support area } \\
\text { C1 }\end{array}$ & $\begin{array}{c}\text { Support areas } \\
\text { C2-C4 }\end{array}$ \\
\hline CAP & $295 € /$ ha & $243 € /$ ha & $243 € / \mathrm{ha}$ & $200 € / \mathrm{ha}$ \\
\hline LFA & $150 € /$ ha & $200 € /$ ha & $200 € /$ ha & $210 € /$ ha \\
\hline National support & $\begin{array}{l}74-215 € / \mathrm{lu} \\
73-392 € / \mathrm{ha}\end{array}$ & $\begin{array}{l}74-215 € / \mathrm{lu} \\
73-392 € / \mathrm{ha}\end{array}$ & $\begin{array}{c}251-410 € / \mathrm{lu} \\
69-185 € / \mathrm{ha}\end{array}$ & $\begin{array}{c}251-1042 € / \mathrm{lu} \\
30-185 € / \mathrm{ha}\end{array}$ \\
\hline
\end{tabular}

Agri-environmental support

Same level of payments in all support areas

Basic measures

93-117 €/ha

Additional measures

$13-24 € /$ ha

Special measures

$65-450 € /$ ha, $168-360 € /$ lu

lu=livestock unit

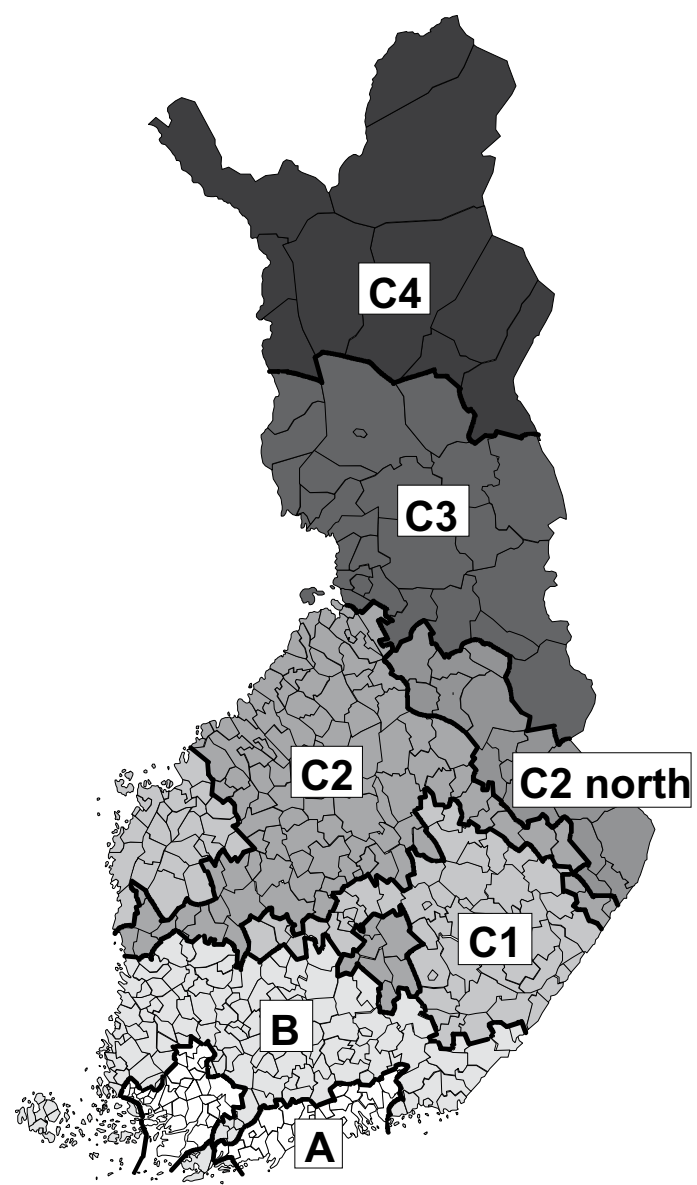

Fig. A1. Agricultural support areas in Finland (Niemi and Ahlstedt 2005). 